\title{
Kualitas Udara Dalam Ruang Rawat Inap Di Rumah Sakit Swasta Tipe C Kota Pekanbaru Ditinjau Dari Kualitas Fisik
}

\author{
Endang Purnawati Rahayu ${ }^{1}$, Zulfan Saam ${ }^{2}$, Sukendi $^{2}$, Dedi Afandi ${ }^{3}$ \\ ${ }^{1}$ Mahasiswa Doktor Ilmu Lingkungan Universitas Riau \\ ${ }^{1}$ STIKes Hang Tuah Pekanbaru email: endangpurnawati90@gmail.com \\ ${ }^{2}$ Program Studi Magister Ilmu Lingkungan Program Pascasarjana Universitas Riau Jalan Pattimura No.09 \\ Gedung.I Gobah Pekanbaru, Telp. 0761-23742 \\ ${ }^{3}$ Fakultas Kedokteran Universitas Riau Jalan Diponegoro No. 01 Pekanbaru Riau
}

\begin{abstract}
Good indoor air quality is free from pollution which can cause irritation, discomfort and occupant health. One room that can be polluted is an inpatient room. to determine the value of air quality in an inpatient room in terms of physical quality. The method used is observation and measurement regarding temperature, humidity and dust of the hospital. The results showed the average temperature of the week in the inpatient room for VIP, class 1, 2, and 3 classes has exceeded the standard quality value. The average humidity of the week in the VIP class and class 1 does not exceed the value of quality standards, in grades 2 and 3 have exceeded the standard quality value. While the average dust per week only in the VIP class, 1 and 2 does not exceed the quality standard, but in class 3 has exceeded the standard quality value. The advice given to hospitals is to do Air Conditioner maintenance on a regular basis, monitoring temperature, humidity and dust in every room as well as routine room cleaning.
\end{abstract}

Key Words: Indoor air quality, Physical quality, Hospital

Udara merupakan suatu hal yang sangat penting bagi kehidupan manusia. Udara memberikan banyak manfaat dan kontribusi bagi kehidupan dibumi ini. Manusia tidak dapat bertahan hidup tanpa udara lebih dari tiga menit. Karena udara berbentuk gas dan terdapat dimana-mana sehingga akibatnya manusia tidak pernah memikirkannya atau memperhatikannya (Soemirat: 2011).

Kualitas udara dalam ruang yang baik didefinisikan sebagai udara yang bebas bahan pencemar penyebab iritasi, ketidaknyamanan atau terganggunya kesehatan penghuni. Temperatur dan kelembaban ruangan juga mempengaruhi kenyamanan dan kesehatan penghuni (Candrasari, dkk: 2013). Salah satu ruangan yang berpotensi mengalami masalah polusi udara dalam ruangan yaitu dirumah sakit. Rumah sakit sebagai tempat pelayanan kesehatan bagi masyarakat harus memiliki ruang rawat inap yang memenuhi syarat kesehatan, baik kualitas udara, konstruksi maupun fasilitas.

Pemerintah Indonesia telah mengatur persyaratan kesehatan lingkungan rumah sakit dalam Keputusan Menteri Kesehatan No. 1204/MENKES/SK/X/2004 yaitu udara di dalam ruang rawat harus bebas kuman patogen dan kadar debu (particulate matter) berdiameter kurang dari 10 micron dengan rata-rata pengukuran 8 jam atau 24 jam tidak melebihi $150 \mu \mathrm{g} / \mathrm{m}^{3}$ dan tidak mengandung debu asbes.

Manusia menghabiskan sebagian besar waktu, sepanjang hari, dalam ruangan di rumah, kantor, sekolah, fasilitas kesehatan, atau tempat publik lainnya. Kualitas udara yang kita hirup di gedung-gedung merupakan faktor penentu penting dari kesehatan. Polusi udara dalam ruangan karena faktor kelembaban, keberadaan mikroorganisme, merupakan penyebab utama morbiditas dan mortalitas di seluruh dunia (WHO, 2009).

Tujuan penelitian: untuk mengetahui nilai kualitas udara dalam ruang rawat inap ditinjau dari kualitas fisik.

Manfaat penelitian: dapat digunakan sebagai informasi dan bahan masukan bagi rumah sakit untuk membuat kebijakan dalam mengelola kualitas udara dalam ruang rumah sakit dan bisa dijadikan sebagai literatur bagi peneliti selanjutnya.

Kualitas udara dalam ruang adalah salah satu aspek keilmuan yang memfokuskan pada kualitas atau mutu udara dalam suatu ruang 
yang dimasukkan kedalam ruang atau gedung yang ditempati manusia, apakah udara yang dipergunakan dalam ruangan atau gedung tersebut memenuhi kesehatan atau sebaliknya (Idham, 2003).

Hasil pemeriksaan The National Institute of Occupational Safety and Health (NIOSH), menyebutkan ada 5 sumber pencemaran di dalam ruangan yaitu (Aditama, 2002):

a. Pencemaran dari alat -alat di dalam gedung seperti asap rokok, pestisida, bahan-bahan pembersih ruangan.

b. Pencemaran di luar gedung meliputi masuknya gas buangan kendaraan bermotor, gas dari cerobong asap atau dapur yang terletak di dekat gedung dimana kesemuanya dapat terjadi akibat penempatan lokasi lubang udara yang tidak tepat.

c. Pencemaran akibat bahan bangunan meliputi pencemaran formaldehid, lem, asbes, fibreglass dan bahan -bahan lain yang merupakan komponen pembentuk gedung tersebut.

d. Pencemaran akibat mikroba dapat berupa bakteri, jamur, protozoa dan produk mikroba lainnya yang dapat ditemukan di saluran udara dan alat pendingin beserta seluruh sistemnya.

e. Gangguan ventilasi udara berupa kurangnya udara segar yang masuk, serta buruknya distribusi udara dan kurangnya perawatan sistem ventilasi udara.

\section{Kualitas Fisik}

\section{Suhu}

Suhu tubuh manusia dipertahankan hampir menetap (homoeotermis) oleh suatu sistem pengatur suhu (thermoregulatory system). Suhu yang lebih dingin katakan $20^{\circ} \mathrm{C}$ (suhu paling cocok bagi penduduk sub-tropis) mengurangi efisiensi kerja dengan keluhan kaku atau kurangnya koordinasi otot. Suhu panas berakibat menurunkan prestasi kerja berfikir, penurunan kemampuan berfikir sangat luar biasa terjadi setelah suhu udara melampaui $32^{\circ} \mathrm{C}$ (Suma'mur : 2014). Menurut Kepmenkes No. 1204/MENKES/SK/X/2004 tentang persyaratan kesehatan lingkungan rumah sakit bahwa suhu udara untuk ruang rawat inap adalah $22-24^{\circ} \mathrm{C}$.

\section{Kelembaban}

Kelembaban udara merupakan konsentrasi uap air di udara. Kelembaban udara diekspresikan sevagai kelembaban relative udara, dalam bentuk presentase kejenuhan tekanan uap air di udara pada suhu tersebut (Harrianto : 2010). Menurut Kepmenkes No. 1204/MENKES/SK/X/2004 tentang persyaratan kesehatan lingkungan rumah sakit bahwa kelembaban udara untuk ruang rawat inap adalah $45-60 \%$.

\section{Debu}

Partikel debu akan ada di udara dalam waktu yang relatif yang lama sehingga masuk ke dalam tubuh manusia melalui pernafasan dan dapat membahayakan kesehatan (Pudjiastuti : 1998). Menurut Kepmenkes No. 1204/MENKES/SK/X/2004 tentang persyaratan kesehatan lingkungan rumah sakit bahwa kadar debu berdiameter kurang dari 10 micron dengan rata-rata pengukuran 8 jam atau 24 jam tidak melebihi $150 \mu \mathrm{g} / \mathrm{m}^{3}$ dan tidak mengandung debu asbes.

\section{BAHAN DAN METODE}

\section{Metode Studi}

Penelitian ini bersifat deskriptif untuk menggambarkan kualitas udara dalam ruang rawat inap rumah sakit yang ditinjau dari kualitas fisik. Populasi pada penelitian ini adalah kualitas fisik udara yang berada diruang rawat inap rumah sakit tipe C Kota Pekanbaru. Sampel penelitian ini adalah mewakili dari setiap kelas VIP, kelas 1, kelas 2 dan kelas 3.

\section{Metode pengumpulan data}

1. Metode observasi: kondisi fisik lingkungan ruang rawat inap yang terdiri dari lantai, dinding, ventilasi, atap, langit-langit, luas lantai, AC.

2. Metode pengukuran: mengukur suhu, kelembaban dan debu didalam ruang rawat inap yang dilakukan selama 1 (satu) minggu.

\section{Metode Analisa}

Hasil pengukuran kualitas fisik yang telah didapat selama satu minggu pengukuran dirumah sakit dengan melihat nilai rata-rata selama satu minggu dengan rumus dibawah ini: 


$$
\bar{x}=\frac{\sum^{\mathrm{k}}{ }_{\mathrm{i}}={ }^{\mathrm{x}}{ }_{1}}{\mathrm{n}}
$$

Keterangan:

$\bar{x}$ : nilai rata-rata

$\mathrm{n}:$ nilai jumlah

$\sum^{\mathrm{k}}{ }_{\mathrm{i}}={ }_{1}^{\mathrm{x}}$ : penjumlahan seluruh data
Kualitas fisik yang diteliti adalah suhu, kelembaban dan debu dalam ruang rawat inap rumah sakit tipe $\mathrm{C}$, pengukuran dilakukan selama 1 (satu) minggu sehingga dari hasil tersebut didapatkan rata-rata kualitas udara ditinjau dari kualitas fisik diruang rawat inap kelas VIP dirumah sakit seperti tabel 1 berikut ini:

\section{HASIL}

Tabel 1. Hasil Pengukuran Kualitas Udara Dalam Ruang Rawat Inap Kelas VIP Rumah Sakit Ditinjau Dari Kualitas Fisik

\begin{tabular}{|c|c|c|c|c|c|c|c|c|c|c|c|}
\hline \multirow[t]{2}{*}{ No } & \multirow[t]{2}{*}{ Kualitas Fisik } & \multirow[t]{2}{*}{ Ruang } & \multicolumn{7}{|c|}{ Hari ke-1 s/d 7} & \multirow{2}{*}{$\begin{array}{c}\text { Rata- } \\
\text { rata }\end{array}$} & \multirow{2}{*}{$\begin{array}{l}\text { Baku } \\
\text { Mutu }\end{array}$} \\
\hline & & & 1 & 2 & 3 & 4 & 5 & 6 & 7 & & \\
\hline \multirow[t]{3}{*}{1} & \multirow[t]{3}{*}{ Suhu $\left({ }^{0} \mathrm{C}\right)$} & VIP.a & 26,2 & 26,7 & 25,5 & 26,6 & 27,0 & 26,1 & 26,5 & 26,3 & \multirow{3}{*}{$22-24$} \\
\hline & & VIP.b & 27,7 & 25,5 & 26,4 & 25,5 & 25,9 & 25,4 & 25,8 & 26,0 & \\
\hline & & VIP.c & 25,7 & 25,3 & 26,7 & 25,4 & 24,0 & 23,5 & 24,6 & 25,0 & \\
\hline \multirow[t]{3}{*}{2} & \multirow{3}{*}{$\begin{array}{l}\text { Kelembaban } \\
(\%)\end{array}$} & VIP.a & 50,4 & 50,7 & 50,9 & 50,7 & 50,4 & 50,6 & 51,4 & 50,7 & \multirow{3}{*}{$45-60$} \\
\hline & & VIP.b & 52,6 & 50,5 & 49,6 & 50,6 & 50,8 & 52,3 & 51,6 & 51,4 & \\
\hline & & VIP.c & 50,1 & 52,7 & 49,1 & 51,8 & 51,1 & 50,7 & 51,6 & 51,0 & \\
\hline \multirow[t]{3}{*}{3} & \multirow{3}{*}{$\begin{array}{l}\text { Debu } \\
\left(\mu \mathrm{g} / \mathrm{m}^{3}\right)\end{array}$} & VIP.a & 40,4 & 41,3 & 43,2 & 41,4 & 42,5 & 40,6 & 41,7 & 41,5 & \multirow{3}{*}{150} \\
\hline & & VIP.b & 43,2 & 41,8 & 42,7 & 44,9 & 41,7 & 43,4 & 42,5 & 42,8 & \\
\hline & & VIP.c & 45,2 & 42,4 & 43,1 & 46,2 & 44,2 & 45,2 & 46,2 & 44,6 & \\
\hline
\end{tabular}

Untuk hasil kualitas udara dalam ruang rawat inap yang ditinjau dari kualitas fisik yang berada di kelas 1 seperti tabel 2 berikut ini:

Tabel 2. Hasil Pengukuran Kualitas Udara Dalam Ruang Rawat Inap Kelas 1 Rumah Sakit Ditinjau Dari Kualitas Fisik

\begin{tabular}{|c|c|c|c|c|c|c|c|c|c|c|c|}
\hline \multirow[t]{2}{*}{ No } & \multirow[t]{2}{*}{ Kualitas Fisik } & \multirow[t]{2}{*}{ Ruang } & \multicolumn{7}{|c|}{ Hari ke-1 s/d 7} & \multirow{2}{*}{$\begin{array}{c}\text { Rata- } \\
\text { rata }\end{array}$} & \multirow{2}{*}{$\begin{array}{l}\text { Baku } \\
\text { Mutu }\end{array}$} \\
\hline & & & 1 & 2 & 3 & 4 & 5 & 6 & 7 & & \\
\hline \multirow[t]{3}{*}{1} & \multirow[t]{3}{*}{ Suhu $\left({ }^{0} \mathrm{C}\right)$} & Kelas 1.a & 28,8 & 28,8 & 27,6 & 26,8 & 27,9 & 28,4 & 28,6 & 28,1 & \multirow[t]{3}{*}{$22-24$} \\
\hline & & Kelas 1.b & 29,4 & 28,6 & 29,4 & 28,4 & 28,1 & 28,3 & 28,2 & 28,6 & \\
\hline & & Kelas 1.c & 28,7 & 28,6 & 27,7 & 28,4 & 27,3 & 26,7 & 26,8 & 27,7 & \\
\hline \multirow[t]{3}{*}{2} & \multirow{3}{*}{$\begin{array}{l}\text { Kelembaban } \\
(\%)\end{array}$} & Kelas 1.a & 55,6 & 56,6 & 55,3 & 55,8 & 55,2 & 55,6 & 54,6 & 55,5 & \multirow[t]{3}{*}{$45-60$} \\
\hline & & Kelas 1.b & 57,2 & 57,1 & 56,4 & 57,2 & 56,2 & 57,4 & 56,8 & 56,9 & \\
\hline & & Kelas 1.c & 55,8 & 55,7 & 54,6 & 54,8 & 54,9 & 55,2 & 55,1 & 55,1 & \\
\hline \multirow[t]{3}{*}{3} & \multirow[t]{3}{*}{ Debu $\left(\mu \mathrm{g} / \mathrm{m}^{3}\right)$} & Kelas 1.a & 45,2 & 45,6 & 46,3 & 45,9 & 45,1 & 47,2 & 46,2 & 45,9 & \multirow[t]{3}{*}{150} \\
\hline & & Kelas 1.b & 47,8 & 48,4 & 48,2 & 47,9 & 46,8 & 48,8 & 47,3 & 47,8 & \\
\hline & & Kelas 1.c & 47,9 & 48,9 & 48,2 & 47,5 & 48,3 & 48,6 & 47,1 & 48,0 & \\
\hline
\end{tabular}

Untuk hasil kualitas udara dalam ruang rawat inap yang ditinjau dari kualitas fisik yang berada di kelas 1 seperti tabel 3 berikut ini:

Tabel 3. Hasil Pengukuran Kualitas Udara Dalam Ruang Rawat Inap Kelas 2 Rumah Sakit Ditinjau Dari Kualitas Fisik

\begin{tabular}{|c|c|c|c|c|c|c|c|c|c|c|c|}
\hline \multirow[t]{2}{*}{ No } & \multirow[t]{2}{*}{ Kualitas Fisik } & \multirow[t]{2}{*}{ Ruang } & \multicolumn{7}{|c|}{ Hari ke-1 s/d 7} & \multirow{2}{*}{$\begin{array}{l}\text { Rata- } \\
\text { rata }\end{array}$} & \multirow{2}{*}{$\begin{array}{l}\text { Baku } \\
\text { Mutu }\end{array}$} \\
\hline & & & 1 & 2 & 3 & 4 & 5 & 6 & 7 & & \\
\hline \multirow[t]{3}{*}{1} & \multirow[t]{3}{*}{ Suhu $\left({ }^{0} \mathrm{C}\right)$} & Kelas 2.a & 28,8 & 28,7 & 29,6 & 29,3 & 28,5 & 27,8 & 28,4 & 28,7 & \multirow[t]{3}{*}{$22-24$} \\
\hline & & Kelas 2.b & 28,6 & 28,6 & 29,7 & 28,4 & 28,9 & 28,1 & 28,5 & 28,6 & \\
\hline & & Kelas 2.c & 28,5 & 28,7 & 28,6 & 29,5 & 29,0 & 28,9 & 28,4 & 28,8 & \\
\hline \multirow[t]{3}{*}{2} & \multirow{3}{*}{$\begin{array}{l}\text { Kelembaban } \\
(\%)\end{array}$} & Kelas 2.a & 59,4 & 59,8 & 59,2 & 59,6 & 58,3 & 59,1 & 58,6 & 59,1 & \multirow[t]{3}{*}{$45-60$} \\
\hline & & Kelas 2.b & 61,6 & 60,4 & 60,3 & 61,5 & 60,6 & 60,2 & 60,5 & 60,7 & \\
\hline & & Kelas 2.c & 59,6 & 58,5 & 59,7 & 58,6 & 58,3 & 58,5 & 59,6 & 58,9 & \\
\hline \multirow[t]{3}{*}{3} & \multirow[t]{3}{*}{ Debu $\left(\mu \mathrm{g} / \mathrm{m}^{3}\right)$} & Kelas 2.a & 67,9 & 69,8 & 67,3 & 69,8 & 68,6 & 67,9 & 68,5 & 68,5 & \multirow[t]{3}{*}{150} \\
\hline & & Kelas 2.b & 69,2 & 70,7 & 68,9 & 69,2 & 70,9 & 72,1 & 70,7 & 70,2 & \\
\hline & & Kelas 2.c & 70,7 & 69,6 & 69,8 & 70,4 & 69,9 & 71,6 & 71,7 & 70,5 & \\
\hline
\end{tabular}

Untuk hasil kualitas udara dalam ruang rawat inap yang ditinjau dari kualitas fisik yang berada di kelas 1 seperti tabel 4 berikut ini: 
Tabel 4. Hasil Pengukuran Kualitas Udara Dalam Ruang Rawat Inap Kelas 3 Rumah Sakit Ditinjau Dari Kualitas Fisik

\begin{tabular}{|c|c|c|c|c|c|c|c|c|c|c|c|}
\hline \multirow[t]{2}{*}{ No } & \multirow{2}{*}{$\begin{array}{c}\text { Kualitas } \\
\text { Fisik }\end{array}$} & \multirow[t]{2}{*}{ Ruang } & \multicolumn{7}{|c|}{ Hari ke-1 s/d 7} & \multirow{2}{*}{$\begin{array}{c}\text { Rata- } \\
\text { rata }\end{array}$} & \multirow{2}{*}{$\begin{array}{l}\text { Baku } \\
\text { Mutu }\end{array}$} \\
\hline & & & 1 & 2 & 3 & 4 & 5 & 6 & 7 & & \\
\hline \multirow[t]{3}{*}{1} & \multirow[t]{3}{*}{ Suhu $\left({ }^{0} \mathrm{C}\right)$} & Kelas 3.a & 29,8 & 29,9 & 29,6 & 28,8 & 29,2 & 28,6 & 29,0 & 29,2 & \multirow[t]{3}{*}{$22-24$} \\
\hline & & Kelas 3.b & 29,5 & 28,7 & 29,7 & 29,4 & 29,7 & 28,6 & 29,4 & 29,2 & \\
\hline & & Kelas 3.c & 28,6 & 28,6 & 28,4 & 28,7 & 29,2 & 28,5 & 28,9 & 28,7 & \\
\hline \multirow[t]{3}{*}{2} & \multirow{3}{*}{$\begin{array}{l}\text { Kelembaban } \\
(\%)\end{array}$} & Kelas 3.a & 65,7 & 65,6 & 67,3 & 65,8 & 65,3 & 66,9 & 66,5 & 66,1 & \multirow[t]{3}{*}{$45-60$} \\
\hline & & Kelas 3.b & 68,1 & 67,1 & 69,1 & 64,1 & 68,1 & 69,7 & 69,1 & 67,9 & \\
\hline & & Kelas 3.c & 68,5 & 68,7 & 69,2 & 67,5 & 68,5 & 69,5 & 69,8 & 68,8 & \\
\hline \multirow[t]{3}{*}{3} & \multirow{3}{*}{$\begin{array}{l}\text { Debu } \\
\left(\mu \mathrm{g} / \mathrm{m}^{3}\right)\end{array}$} & Kelas 3.a & 210,7 & 200,0 & 190,8 & 200,8 & 192,7 & 198,6 & 189,7 & 197,6 & \multirow[t]{3}{*}{150} \\
\hline & & Kelas 3.b & 243,2 & 226,0 & 236,2 & 256,0 & 212,8 & 240,2 & 248,0 & 237,4 & \\
\hline & & Kelas 3.c & 178,5 & 179,4 & 188,5 & 189,4 & 178,9 & 187,5 & 189,9 & 184,5 & \\
\hline
\end{tabular}

Tabel 5. Observasi dilapangan mengenai kualitas fisik

\begin{tabular}{|c|c|c|}
\hline No & Karakteristik & Kondisi Ruang Rawat Inap \\
\hline 1 & Lantai & $\begin{array}{l}\text { Keramik masih dalam kondisi bagus dan berwarna terang namun sudut } \\
\text { ruangan (keramik) masih ada siku }\end{array}$ \\
\hline 2 & Dinding & $\begin{array}{l}\text { Terbuat dari batu bata dan diplester dengan cat tembok berwarna terang } \\
\text { namun ada beberapa ruangan catnya sudah mulai rusak }\end{array}$ \\
\hline 3 & Ventilasi & $\begin{array}{l}\text { Sistem ventilasi buatan tidak ada ventilasi alami karena ruangan } \\
\text { menggunakan } \mathrm{AC}\end{array}$ \\
\hline 4 & Atap & Masih dalam kondisi bagus tidak ada yang bocor \\
\hline 5 & Langit-langit & Kondisi bagus tidak ada yang rusak \\
\hline 6 & Luas lantai & Belum sesuai dengan rasio luas lantai dengan tempat tidur \\
\hline 7 & $\mathrm{AC}$ & AC split, jumlah AC setiap ruangan berbeda dan jumlah juga berbeda \\
\hline
\end{tabular}

\section{PEMBAHASAN}

Dari hasil penelitian diatas yang terlihat pada tabel 1 dan 2 mengenai pengukuran kualitas udara dalam ruang rawat inap kelas vip rumah sakit ditinjau dari kualitas fisik didapatkan bahwa rata-rata perminggu suhu telah melebihi nilai baku mutu namun kelembaban dan debu masih dibawah nilai baku. Apabila dilihat hasil pada tabel 3 khusus ruang rawat inap kelas 2 bahwa rata-rata perminggu suhu telah melebihi nilai baku mutu, kelembaban ada pada satu ruangan yang telah melebihi nilai baku mutu dan debu masih dibawah nilai baku mutu. Sedangkan hasil pada tabel 4 khusus ruang rawat inap kelas 3 bahwa rata-rata perminggu suhu, kelembaban dan debu telah melebihi nilai baku mutu.

Rata-rata semua ruang rawat inap rumah sakit telah melebihi nilai baku mutu maka kondisi ruang rawat inap terasa sedikit panas. Kondisi ini dipengaruhi oleh berbagai faktor antara lain jumlah pasien, jumlah penunggu dan jumlah pengunjung serta kapasitas AC dalam satu ruangan sehingga suhu ruangan pun menjadi meningkat, selain itu kondisi cuaca yang panas seiring dengan bertambahnya intensitasi sinar matahari yang masuk kedalam ruangan juga bisa menyebabkan tingginya suhu ruang.

Suhu berperan penting dalam mengatur jalannya reaksi metabolisme bagi semua makhluk hidup, khususnya bagi bakteri. Suhu lingkungan yang berada lebih tinggi dari suhu yang dapat ditoleransi akan menyebabkan denaturasi protein dan komponen esensial lainnya sehingga sel akan mati. Demikian pula apabila suhu lingkungan berada dibawa batas toleransi, membran sitoplasma tidak akan berwujud cair sehingga transportasi nutrisi akan terhambat dan proses kehidupan sel akan terhenti. Suhu yang tinggi bisa mengganggu kondisi pasien karena ruangan yang panas dapat menyebabkan pasien menjadi gelisah dan tidak nyaman sehingga tidak bisa beristirahat. Hal ini sejalan dengan penelitian Jayanti (2016) bahwa suhu rata-rata yang didapat dari pengukuran diruang rawat inap RS Syekh Yusuf Kabupaten Gowa $>30^{\circ} \mathrm{C}$ yang telah melebihi nilai baku mutu.

Hasil dari Northen European Studies bahwa ada hubungan antara peningkatan temperature sekitar $23^{\circ} \mathrm{C}$, kepadatan penghuni dan ventilasi terhadap gejala-gejala ketidak 
nyamanan dalam ruangan. Bila suhu $>28^{\circ} \mathrm{C}$ perlu menggunakan alat penetral udara seperti Air Conditioner (AC), kipas angin.

Untuk kelembaban yang melebihi nilai baku mutu hanya diruang rawat inap kelas 2 dan 3 , kondisi ini bisa dipengaruhi oleh suhu, tidak adanya ventilasi alami diruangan sehingga sirkulasi udara menjadi kurang maksimal dan kondisi cat dalam ruangan sehingga berpotensi adanya pertumbuhan mikroorganisme sehingga menyebabkan kelembaban menjadi tinggi.

Kelembaban udara yang relatif rendah yaitu kurang dari 20\% dapat menyebabkan kekeringan selaput lendir membran, sedangkan kelembaban tinggi akan meningkatkan pertumbuhan mikroorganisme. Maka hasil dari pengukuran di RS yang berada diatas standar yang berarti potensial sebagai tempat pertumbuhan mikroorganisme. Hal ini sejalan dengan penelitian yang dilakukan Nizar (2011) rata-rata hasil pengukuran kelembaban pada saat melakukan penelitian di RSUD Prof. Dr. Margono Soekarjo Purwekerto sebanyak $68,25 \%$ tidak memenuhi syarat Kepmenkes RI No.1204/ Menkes/SK/X/2004.

Untuk debu yang melebihi nilai baku mutu hanya diruang rawat inap kelas 3, ini disebabkan karena banyaknya aktivitas dalam ruang rawat inap kelas 3 dengan jumlah orang yang banyak seperti jumlah pasien, jumlah penunggu dan jumlah pengunjung serta rutinitas pembersihan ruangan sangat diperlukan untuk mengurangi debu dalam ruang. Kondisi ini bisa dipengaruhi oleh beberapa faktor antara lain $\mathrm{Hal}$ ini sejalan dengan penelitian Jayanti (2016) bahwa debu rata-rata yang didapat dari pengukuran diruang rawat inap RS Syekh Yusuf Kabupaten Gowa $<150 \mu \mathrm{g} / \mathrm{m}^{3}$ yang telah melebihi nilai baku mutu.

\section{SIMPULAN}

Kualitas udara dalam ruang rawat inap yang dilihat dari kualitas fisik bahwa untuk variabel suhu rata-rata perminggu pada kelas VIP, 1, 2 dan 3 telah melebihi nilai baku mutu, variabel kelembaban rata-rata perminggu pada kelas VIP dan kelas 1 tidak melebihi nilai baku mutu namun pada kelas 2 dan 3 telah melebihi nilai baku mutu. Sedangkan variabel debu rata-rata perminggu hanya pada kelas VIP, 1 dan 2 tidak melebihi bau mutu, namun pada kelas 3 yang telah melebihi nilai baku mutu. Saran yang diberikan kepada rumah sakit untuk mengantisipasi hal ini adalah dengan melakukan perawatan AC secara berkala minimal 6 bulan sekali, melakukan monitoring suhu, kelembaban dan debu disetiap ruangan serta melakukan pembersihan ruangan secara rutin 2 kali dalam sehari.

\section{UCAPAN TERIMA KASIH}

Terimakasih saya ucapkan kepada pihak manajemen rumah sakit yang telah memberikan ijin untuk melakukan penelitian dan semua pihak yang telah membantu proses penelitian ini.

\section{DAFTAR PUSTAKA}

Candrasari cahyatri rupisianing. Mukono J. hubungan kualitas udara dalam ruang dengan keluhan penghuni lembaga pemasyarakatan kelas IIA kabupaten sidoarjo. Jurnal kesehatan lingkungan vol.7 no.1 juli 2013.

Departemen Kesehatan RI. Keputusan menteri kesehatan republic Indonesia nomor 1204/MENKES/SK/X/2004 tentang persyaratan kesehatan lingkungan rumah sakit. Jakarta: Departemen Kesehatan RI; 2004.

Rendra S, Pudjiastuti L, Sentosa HR. Kualitas udara dalam ruang. Jakarta: Direktorat Jenderal Pendidikan Tinggi Departemen Pendidikan dan Kebudayaan RI; 1998.

Soemirat, Juli. 2011. Kesehatan Lingkungan. Revisi. UGM. Gadjah Mada University Press. Yogyakarta.

Suma'mur. 2013. Higiene Perusahaan dan Kesehatan Kerja (HIPERKES). Sagung Seto. Jakarta. 